\title{
Influence of Temperature on Cambial Activity and Cell Differentiation in Quercus Sessiliflora and Acer Pseudoplatanus of Different Ages
}

\section{Utjecaj promjena temperature na djelovanje kambija i diferencijaciju stanica drva hrasta kitnjaka i gorskog javora različite dobi}

\author{
Original scientific paper • Izvorni znanstveni rad \\ Received-prispjelo: 10. 9. 2012. \\ Accepted-prihvaćeno: 15. 2. 2013. \\ UDK: $630 * 811.12 ; 630 * 811.13 ; 674.031 .11$ \\ doi:10.5552/drind.2013.1246
}

\begin{abstract}
We evaluated the response of active cambium of sessile oak (Quercus sessiliflora) and sycamore maple (Acer pseudoplatanus) to experimentally increased $\left(20-22^{\circ} \mathrm{C}\right)$ and decreased $\left(9-11^{\circ} \mathrm{C}\right)$ temperatures. Heating and cooling experiments on 150-year old Q. sessiliflora were performed during the growth season of 2007 and on 30-year old A. pseudoplatanus in 2008. In 2009, heating experiment was carried out on 30-year old Q. sessiliflora. For each treatment, two trees were selected of each species and sampled at 21-day intervals during the vegetation period and investigated by means of light microscopy. Continuously elevated temperatures slightly promoted the development of xylem cells in old Q. sessiliflora trees in the first month of cambial activity. However, no effect of elevated or decreased temperature was detected in the timing and dynamics of wood and phloem formation. The applied treatments, therefore, had no visible impact on the structure or width of the xylem or phloem increments in 2007. On the other hand, heating young A. pseudoplatanus trees provoked the development of epicormic shoots two months after the onset of the experiment and finally the death of trees. The cambium of those trees did not reactivate in 2008; xylem and phloem increments were consequently not formed. Low temperature treatments slowed down cell production at the very beginning of the growing season, but no alterations in wood or phloem formation dynamics or structure were observed later. The heating of young $Q$. sessiliflora trees caused the development of epicormic shoots and the death of trees four months after the experiment. The pattern of their dying was similar as in A. pseudoplatanus but with a two month delay. The observations indicate that tree age, thickness of dead bark and duration of the applied treatments influence the response of cambium. The development of dead bark is species specific and it occurs earlier in Q. sessiliflora than in A. pseudoplatanus. Thick dead bark acts as a very good insulation layer for the sensitive internal, living tissues of bark and cambium and therefore protects them against external abiotic and biotic factors.
\end{abstract}

Key words: sessile oak, sycamore maple, heating, cooling, cambium, cell differentiation, xylem, phloem, dead bark, light microscopy

\footnotetext{
Author is assistant professor at Slovenian Forestry Institute, Department of Yield and Silviculture, Ljubljana, Slovenia. ${ }^{1}$ Autorica je docentica Slovenskoga šumarskog instituta, Odjel za prirast i silvikulturu, Ljubljana, Slovenija.
} 
SAŽETAK • U radu je istraživan utjecaj grijanja $\left(20-22{ }^{\circ} \mathrm{C}\right)$ i hlađenja $\left(9-11^{\circ} \mathrm{C}\right)$ na djelovanje kambija $i$ stvaranje drva i floema u dijelu debla 150 i 30 godina starog hrasta kitnjaka (Quercus sessiliflora) i 30 godina staroga gorskog javora (Acer pseudoplatanus). U svakom tretmanu odabrali smo dva stabla svake od tih vrsta i skupili uzorke u 21-dnevnim intervalima tijekom vegetacije, koje smo analizirali svjetlosnom mikroskopijom. Stalno povišena temperatura potaknula je nešto raniji početak stvaranja stanica drva u starim stablima Q. sessiliflora u prvome mjesecu kambijske aktivnosti u 2007. Međutim, učinak povišene ili smanjene temperature na vrijeme ili dinamiku stvaranja drva i lika nismo potvrdili. Stoga, tretmani nisu utjecali na strukturu i širinu goda drva $i$ lika u 2007. Nasuprot tome, grijanje mladih stabala A. pseudoplatanus potaknulo je razvoj adventivnih izdanaka dva mjeseca nakon pokusa i na kraju prouzročila njihovu smrt. Kambij se u tim uzorcima u 2008. nije reaktivirao, stoga se nije formirao ni god drva i lika. Niske temperature usporile su proizvodnju stanica u kambiju na samom početku vegetacije, ali nisu utjecale na dinamiku stvaranja ili strukturu drva i lika. Grijanje mladih stabala $Q$. sessiliflora rezultiralo je nastankom adventivnih izdanaka i umiranjem stabala četiri mjeseca nakon eksperimenta. Proces umiranja bio je sličan umiranju stabala A. pseudoplatanus, samo uz dva mjeseca zakašnjenja. Promatranja pokazuju da starost stabala (debljina mrtve kore) i trajanje primijenjenih tretmana također mogu utjecati na djelovanje kambija. Početak stvaranja mrtve kore specifičan je za pojedine vrste drveća i ranije se pojavljuje u vrste $Q$. sessiliflora nego u A. pseudoplatanus. Debela mrtva kora djeluje kao vrlo dobar izolacijski sloj za unutarnja, živa i osjetljiva tkiva (floem i kambij) i stoga ih štiti od vanjskih abiotičkih i biotičkih čimbenika.

Ključne riječi: hrast kitnjak, gorski javor, grijanje, hlađenje, kambij, stanična diferencijacija, drvo, liko, mrtva kora, svjetlosna mikroskopija

\section{INTRODUCTION 1. UVOD}

Wood is a natural product of the growth of trees. As a material, it is still essential to mankind, but has evolved over the ages from a simple, natural material into a modern industrial and engineering material. It is produced by the vascular cambium, which in temperate and boreal climatic zones expresses annual periodicity. Seasonal alternations of active and dormant (resting) periods are generally associated with exchanges of hot and cold or dry and rainy seasons (Larcher, 2003). This periodicity plays an important role in the formation of wood and reflects the environmental adaptivity of trees to the growing conditions (Begum et al, 2012).

Cambial activity usually starts in spring with cell division and ends in late summer with the completed development of the latest formed cells. At the beginning of cambial activity, the number of cambial cells increases and they start to divide, which is followed by differentiation of derivatives into the adult elements of xylem or phloem (Plomion et al, 2001). Xylo- and phloemogenesis, which lead to specialization of cells, are periodic processes driven by a variety of internal and external factors, whose influence changes during the growing season. These complex processes are not pre-determined, but are plastic end-products of interactions between the genotype and the environment (Savidge, 2001). Environmental signals affect the beginning, cessation and rate of individual developmental processes, which determine the morphology of cells (Sundberg et al, 2000; Wodzicki, 2001). Despite numerous studies, the mechanism of wood and phloem formation is still not fully explained (Chaffey, 2002); however, a detailed knowledge of all these processes will improve our un- derstanding of the relationship among wood structure, properties and end-use of wood.

The effect of specific climatic factors on the mechanism of xylem and phloem growth ring formation can be studied on trees growing in their natural environment or under experimentally controlled conditions (e.g., Oribe et al, 2001; Gričar et al, 2006; Begum et al, 2008, 2010). Additionally, many controlled experiments have been performed on growing seedlings or saplings, allowing simulation of different growing conditions on the growth and adaptivity of young trees (e.g. Rossi et al, 2009; De Luis et al, 2011). However, to predict the response of different (adult) tree species and forests to possibly changed climate conditions, long-term adaptive responses and highly flexible resource allocation patterns in these long-lived plants must be taken into account. This makes simple extrapolation from laboratory seedling or sapling studies to mature forests difficult if not impossible (Meier and Leuschner, 2008).

Experiments on adult trees are more complicated and are usually restricted to a part of a tree (e.g., stem, branch). It has been demonstrated that the application of temperature in the period of either cambial activity or dormancy can cause alterations in its regular rhythm of periodicity and cell differentiation (e.g., Denne and Dodd, 1981; Mellerowicz et al, 1992; Barnett and Miller, 1994; Oribe and Kubo, 1997; Oribe et al, 2001; Gričar et al, 2006, 2007; Begum et al, 2007, 2008). The application of heat has revealed differences in the response of dormant cambium to treatments among different species of evergreen and deciduous habit (e.g., Oribe et al, 2003; Gričar et al, 2006; Begum et al, 2010); however, in all cases, temperature has been proven to be crucial for the onset of cell division and 
cell development at the beginning of the growing season, while other factors prevail in the second part (Gričar et al, 2007).

The majority of such experiments have been carried out on conifers and, recently, on the deciduous diffuse-porous hardwood Populus sieboldii $x$ Populus grandidentata (Begum et al, 2007) but information on ring-porous species is still lacking. In addition, the effect of elevated temperature on cambial activity has been mostly investigated during dormancy over short periods of time, while only a few studies have been performed during the vegetation period or with decreased temperature. Moreover, the age of the tree has only rarely been taken into consideration as one of the factors that could affect the response of trees to applied treatments (Begum et al, 2010). We, therefore, evaluated the response of active cambium of deciduous ringporous sessile oak (Quercus sessiliflora Salisb.) and diffuse-porous sycamore maple (Acer pseudoplatanus L.) to experimentally increased $\left(20-22{ }^{\circ} \mathrm{C}\right)$ and decreased $\left(9-11^{\circ} \mathrm{C}\right)$ temperatures. Experiments on 150year old $Q$. sessiliflora were performed during the growth season of 2007, on 30-year old A. pseudoplatanus in 2008 and on 30-year old Q. sessiliflora in 2009. Samples of bark, cambium and xylem were taken at 21-day intervals and investigated by means of light microscopy.

\section{MATERIAL AND METHODS 2. MATERIJALI I METODE}

The experiments were performed in the forest site Rožnik in Ljubljana $\left(46^{\circ} 03^{\prime} \mathrm{N}, 14^{\circ} 28^{\prime} \mathrm{E}, 323 \mathrm{~m}\right.$ a.s.1.), which belongs to the Blechno fagetum forest association. The predominant tree species at the site are Fagus sylvatica and Quercus sessiliflora. The climate on the location is humid continental. Average, maximum and minimum daily air temperatures during the experiments were recorded by a weather station located $50 \mathrm{~m}$ from the test trees. For the study, we selected six dominant, healthy sessile oaks (Quercus sessiliflora Salisb.) at the beginning of the vegetation period of 2007. The trees were about 150 years old, with a DBH of $55-80 \mathrm{~cm}$ (considered to be old oaks). In winter 2008, we chose six dominant, healthy sycamore maples (Acer pseudoplatanus L.). The trees were about 30 years old, with a DBH of about $15 \mathrm{~cm}$. Two trees of each species were used for the heating experiment and two for the cooling treatment. Two trees were not treated and served as controls. In winter 2009, we selected four dominant, healthy $Q$. sessiliflora trees. The trees were assessed to be approximately 30 years old, with a DBH of about $15 \mathrm{~cm}$ (considered to be young oaks). Two trees were used for the heating experiment and two for control. The crowns of all selected trees appeared to be normally developed and the trunks to be without any visible mechanical injuries. The distance between the test trees was about $10 \mathrm{~m}$.

Localized heating and cooling of the stem portion of the old $Q$. sessiliflora was performed in the period between 30 March and 12 September 2007, and cooling between 26 April and 12 September 2007. In the case of $A$. pseudoplatanus, heating was carried out in the period 29 February - 15 September 2008 and cooling between 10 April and 15 September 2008. In 2009 , only heating experiments were carried out in young $Q$. sessiliflora in the period $10 \mathrm{March}-17 \mathrm{Sep}-$ tember. The stem portion of the two trees of each species were heated with a $15 \mathrm{~m}$ long electric heat cable (FSM-17, $17 \mathrm{~W} /+5^{\circ} \mathrm{C}, 11 \mathrm{~W} / 25^{\circ} \mathrm{C}, 230 \mathrm{~V}$ ) wrapped around 1 meter of the stem length. The lower part of the heating system was $70 \mathrm{~cm}$ above the ground. Insulation material was wrapped around the electric heat cable to prevent energy loss. The temperature between the bark and the insulation was adjusted to $20-22{ }^{\circ} \mathrm{C}$, and monitored daily with a thermometer sensor. For cooling of the stem portion of the selected trees, we used a circulating pump that pushed cooled water through copper tubes, which were wrapped around 1 meter of the stem length. The system was carefully insulated. The temperature between the stem and the insulation was set to $9-11{ }^{\circ} \mathrm{C}$, monitored and regulated daily with a capillary thermostat.

We took blocks of intact tissue $(10 \times 10 \times 30 \mathrm{~mm})$ containing bark, cambium and outer xylem from living trees $1.3 \mathrm{~m}$ above ground at 21-day intervals. At the beginning of the heating experiment, we took the first three samples at 3-day intervals. The distance between neighbouring samples was at least $10 \mathrm{~cm}$ in a horizontal direction to avoid the influence of wounds on tissues of the next sampling locations. The insulation was replaced in the original position after each sampling. After sampling, blocks of tissue were immediately fixed in FEA (formaldehyde-ethanol-acetic acid solution), dehydrated after one week in a graded series of ethanol and reduced to a size of $2 \times 2 \times 5 \mathrm{~mm}$ for embedding in paraffin (for details see Rossi et al, 2006). Permanent cross-sections of $13 \mu \mathrm{m}$ thickness for light microscopy were prepared on a rotary microtome Leica RM 2245, using disposable Leica blades. Sections were stained with safranin and astra blue and finally mounted in Euparal. An Olympus BX51 light microscope and the Nikon NIS-Elements Basis Research v.2.3 analysis system were used for anatomical observations and evaluation of the developing tissue.

We followed the cambial activity and the development of the xylem and phloem elements on the cross-sections. We distinguished among radially flattened cambial cells with blue stained, thin primary cell walls and xylem and phloem cells at various stages of development (i.e., post-cambial growth, secondary cell wall synthesis and lignification) and mature cells. An increase in the number of cells in the cambium indicated its divisional activity. Expanding cells with thin primary walls between the cambium and a zone of xylem cells with secondary walls were considered to be xylem cells in the stage of post-cambial growth. The initiation of secondary wall thickening was determined by birefringence of the cell walls under polarized light. Blue-stained inner parts of cell walls and the protoplasmic content in the cell lumina indicated incompletely developed xylem cells. Fully matured xylem cells had 
red-stained cell walls and empty lumina. On the phloem side, we observed the timing and formation of early and late phloem sieve tubes and fibres.

At the end of each experiment, we took additional blocks of intact tissue of bark $(10 \times 10 \times 30 \mathrm{~mm})$ from living trees $1.3 \mathrm{~m}$ above ground and measured the thickness of dead bark. Moreover, in 2009 we sampled 70 years old Norway spruce trees, with a DBH of about $35 \mathrm{~cm}$, which we used for heating experiments carried out in 2004 and 2005 for our previous studies (Gričar et al, 2006, 2007) in order to examine the possible relationship between heating effect on cambial activity and cell differentiation with tree age and thickness of dead bark in various tree species.

\section{RESULTS}

\section{REZULTATI}

\subsection{Temperature profiles}

3.1. Temperaturni profili

Climate data for the period between 20 March and 20 September 2007 are shown in Fig. 1a. At the beginning of the experiment, at the end of March, minimum air temperatures were above freezing and maximum about $10^{\circ} \mathrm{C}$. April and May were dry, with the sum of precipitation less than $40 \mathrm{~mm}$ in both months together. In the middle and at the end of May, two short, colder periods were recorded, when maximum temperatures fell below $20^{\circ} \mathrm{C}$ and minimum below $10{ }^{\circ} \mathrm{C}$. June and July were relatively wet (116 and $141 \mathrm{~mm}$, respectively) with maximum temperatures frequently above $30{ }^{\circ} \mathrm{C}$, especially in mid-July. At the end of August, average temperatures slowly started to decrease to about $15^{\circ} \mathrm{C}$ and remained unchanged until the treatments ended.

The daily average, maximum and minimum air temperatures and amount of precipitation recorded in the area from 1 February to 30 September 2008 are shown in Fig. 1b. At the beginning of the experiment, at the end of February, minimum air temperatures were above freezing and maximum about $10^{\circ} \mathrm{C}$. Average temperatures in March varied within the usual limits; from 0 to $10{ }^{\circ} \mathrm{C}$. The amount of precipitation in March and April was above the long-term average - 163 and
$138 \mathrm{~mm}$, respectively. In April, temperatures gradually increased, with minimum temperatures around $5{ }^{\circ} \mathrm{C}$ and maximum often about $20^{\circ} \mathrm{C}$. Maximum temperatures reached $30{ }^{\circ} \mathrm{C}$ at the end of May. In mid- June, a short, colder period was recorded, when maximum temperatures fell below $20{ }^{\circ} \mathrm{C}$. Frequent interruptions of warm periods by heavy storms in combination with cold fronts were typical of July and August 2008. Those two months were above average wet, with more than $170 \mathrm{~mm} /$ per month of precipitation recorded. The first third of September was warm and sunny, but the rest of the month was cooler and drier than usual.

The climate diagram spanning 1 February to 30 September 2009 is shown in Fig. 1c. We started with the heating experiment in mid-March, when minimum air temperatures were around freezing and maximum about $10-15{ }^{\circ} \mathrm{C}$. March was warm and above-average wet, but precipitation was concentrated mainly in the first and the last weeks of the month. April and May were considerably warmer and sunnier than average. In addition, May was dry, with only $52 \mathrm{~mm}$ (48\% of the average amount) of precipitation recorded. June and July were relatively wet months, with $170 \mathrm{~mm}$ of precipitation in each month, mainly expressed as showers or storms. In Ljubljana, average temperatures were 3.3 ${ }^{\circ} \mathrm{C}$ in August and $1.9{ }^{\circ} \mathrm{C}$ in September higher than long-term average. In addition, only half the amount of precipitation was recorded in the mentioned months ( $77 \mathrm{~mm}$ in August and $64 \mathrm{~mm}$ in September).

\subsection{Experiments on old Q. sessiliflora trees in 2007}

3.2. Eksperimenti na starim stablima $Q$. sessiliflora u 2007.

When we started the heating experiment, on 30 March 2007, cell divisions in the cambium of old $Q$. sessiliflora trees had already started. The walls of the cambial cells were very thin and their number had increased up to 10 cell layers. Newly formed xylem cells (early wood vessels and fibres) adjacent to the cambium slowly began to expand. The development of the first early wood vessels progressed very rapidly. We observed some differences between heated and control samples in mid-April. The formation of early
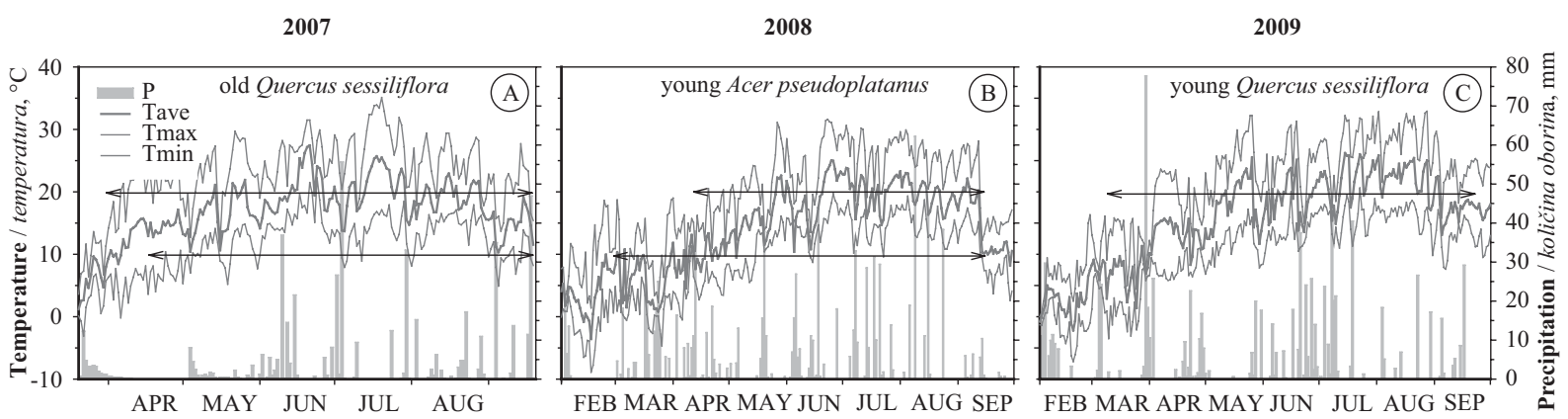

Figure 1 Average, maximum and minimum daily air temperatures and amount of precipitation in Ljubljana $\left(46^{\circ} 03^{\prime} \mathrm{N}\right.$, $14^{\circ} 28^{\prime} \mathrm{E}, 323 \mathrm{~m}$ a.s.1.) in 2007,2008 and 2009 ; during the experiments; the duration of the heating (to $20-22^{\circ} \mathrm{C}$ ) and cooling (to $9-11^{\circ} \mathrm{C}$ ) experiments is indicated by horizontal arrows

Slika 1. Prosječne, maksimalne i minimalne dnevne temperature te količina oborina u Ljubljani $\left(46^{\circ} 03^{\prime} \mathrm{N}, 14^{\circ} 28^{\prime} \mathrm{E}, 323 \mathrm{~m}\right.$ a.s.1.) u 2007, 2008. i 2009; za vrijeme pokusa; trajanje pokusa grijanja (do $20-22^{\circ} \mathrm{C}$ ) /hlađenja (do $9-11{ }^{\circ} \mathrm{C}$ ) naznačeno je strelicama 

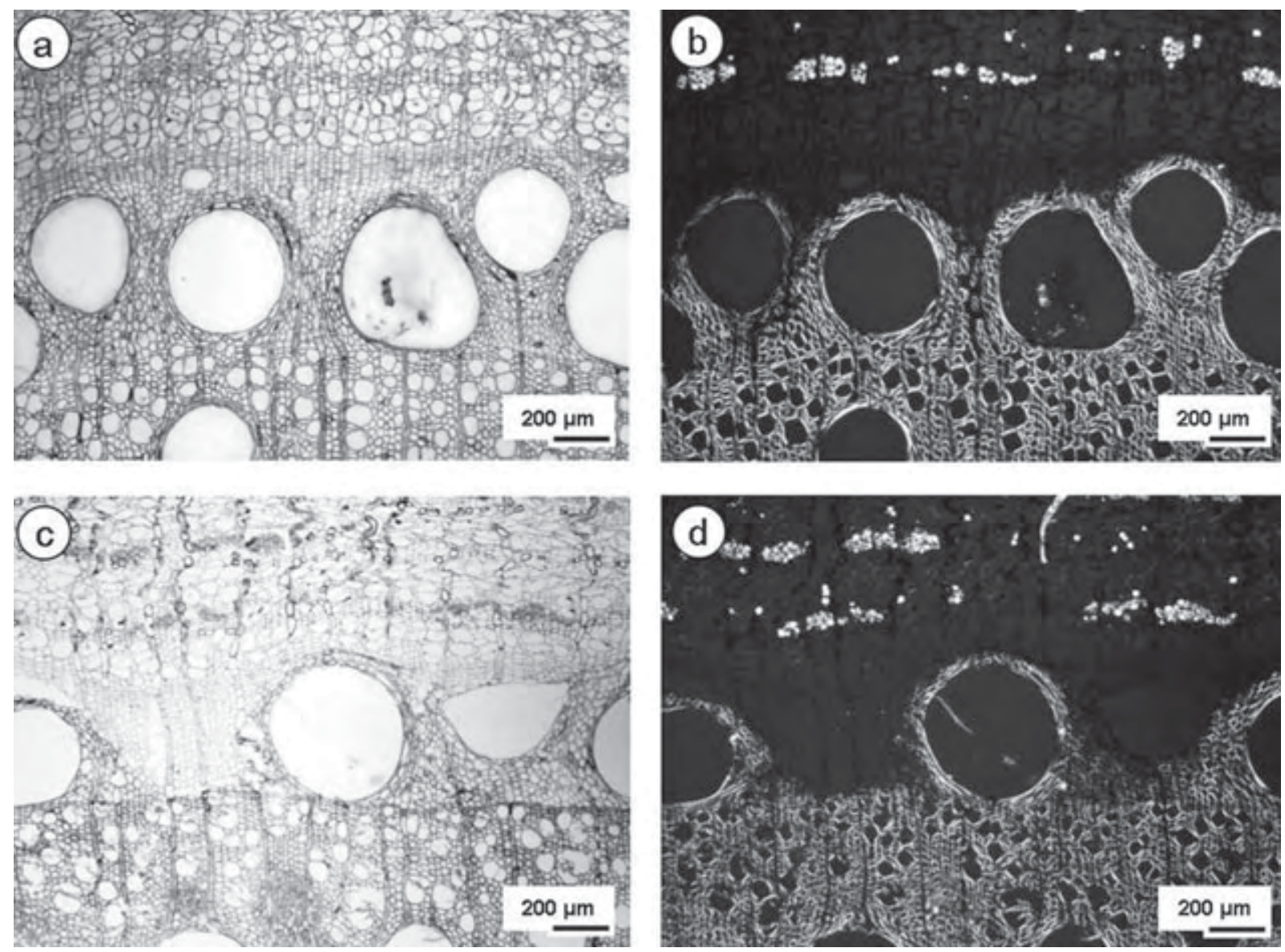

Figure 2 Development of the xylem growth ring in old Quercus sessiliflora in the second part of April 2007; more progressive development in the heated sample ( $\mathrm{a}$ - bright-field and $\mathrm{b}$ - polarized light) than in the control sample ( $\mathrm{c}$ - bright field and $\mathrm{d}$ - polarized light)

Slika 2. Razvoj ksilema u starim stablima Q. sessiliflora u drugoj polovici travnja 2007; brži razvoj u grijanom uzorku (a obična svjetlost i b - polarizirana svjetlost) u usporedbi s kontrolom (c-obična svjetlost i d - polarizirana svjetlost)

wood vessels occurred faster in the heated samples, resulting in complete formation of the first ring of vessels at that time. The vessels and neighbouring tissue were almost completely lignified, whereas the walls of the remaining tissue were still being created. This temporal delay between the development of the vessel together with neighbouring tissue and the remaining tissue was detected during the entire growth ring formation period and is consistent with earlier observations of other authors in various hardwood species (e.g. Mellerowicz et al, 2001; Grünwald et al, 2002; Gričar, 2010). On the other hand, secondary cell walls of early wood vessels and neighbouring tissue in control samples were noticeably less developed, as clearly demonstrated under polarized light (Fig. 2). Moreover, the remaining tissue began to thicken (but not to lignify) only at the growth ring boundary. However, in the further development and dynamics of xylem growth ring formation of 2007, we could not detect any difference between heated and control samples.

We started the cooling experiment in the first week of May, but found no differences in the wood formation pattern among cooled, heated and control samples. The transition from early- to latewood occurred in
mid-May and was identified by a decreasing diameter of the vessels, which were no longer arranged in characteristic rings. The rate of radial growth in this period slowed down. Divisions in the cambium ended in midAugust in all of the investigated samples. The number of cambial cells was reduced to 5-6 cell layers wide and the latest formed xylem cells were still developing. The formation of the xylem growth ring of 2007 was finished by the end of September.

On the phloem side, at the beginning of our experiment at the end of March we observed the first layer of expanding sieve tube elements, accompanied by companion cells and axial parenchyma. The effect of elevated and decreased temperature on phloem formation was negligible. Typical phloem fibres that are found in tangentially orientated groups began to form the secondary cell wall in the second part of May in the heated samples, while wall thickening of the fibres in the control and cooled samples was detected a little later; at the beginning of June (Fig. 3). Late phloem formation occurred in the second part of the growing season and ceased in mid-August. With the exception of the delayed development of the phloem fibres, no differences in formation of the phloem growth ring of 2007 were observed among the groups (Fig. 4). 

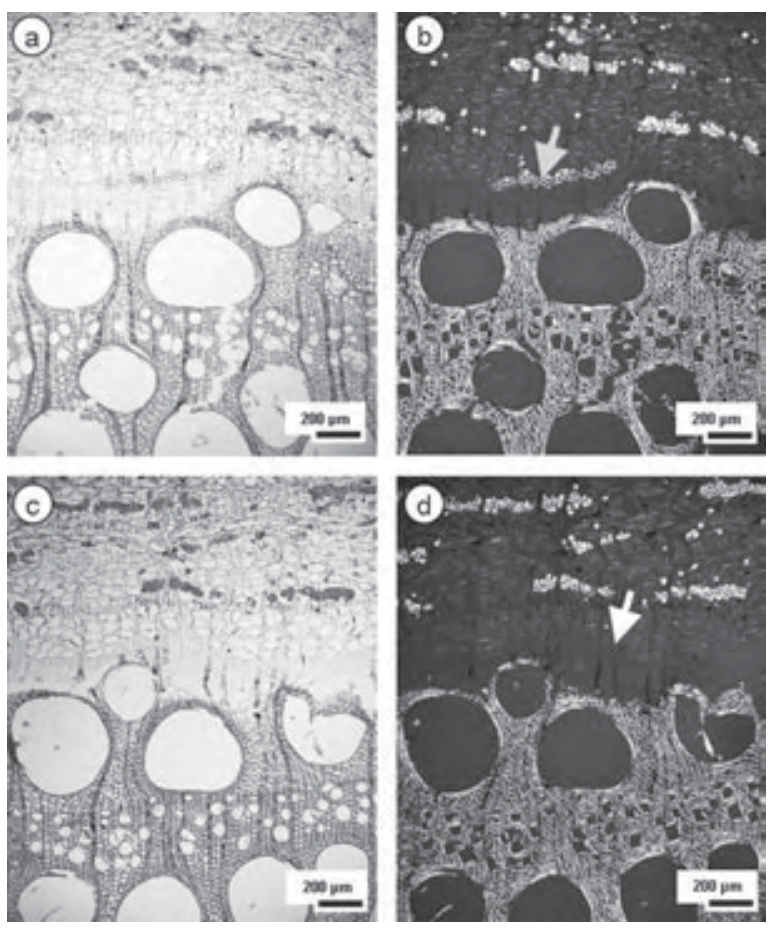

Figure 3 Development of the phloem in old Quercus sessiliflora in mid-May 2007; phloem fibres (orange arrow) in the heated trees $(\mathrm{a}-$ bright field and $\mathrm{b}$ - polarized light), but no fibres (white arrow) in the control trees (c-bright field and $\mathrm{d}$ - polarized light)

Slika 3. Razvoj floema u starim stablima (Quercus sessiliflora) sredinom svibnja 2007.g.; floemska vlakna (narančaste strelice) u grijanim stablima (a - obična svjetlost i b - polarizirana svjetlost) i nedostatak vlakana (bijele strelice) u kontrolnim i hlađenim stablima (c - obična svjetlost i $\mathrm{d}$ - polarizirana svjetlost)

In order to establish possible differences among heated, cooled and control samples, we measured the widths of the xylem and phloem growth rings of 2007 and calculated the ratio between xylem and phloem increments for each tree group (Table 1). Xylem and phloem ring widths differed among sampled trees due to high variability within a single tree and also among trees. The presence of variability in xylem and phloem
Table 1 Widths of xylem and phloem growth rings of 150 years old Quercus sessiliflora, and the ratio between phloem and xylem increments in 2007 for each tree group

Tablica 1. Širina ksilema i floema goda 150 godina starog hrasta (Quercus sessiliflora) formiranoga u 2007. g. te njihov omjer u svakoj testiranoj skupini drveća

\begin{tabular}{|l|c|c|c|}
\hline $\begin{array}{l}\text { Tree group } \\
\text { Skupina stabla }\end{array}$ & $\begin{array}{c}\text { Xylem, } \boldsymbol{\mu m} \\
\text { Ksilem, } \mu \mathrm{m}\end{array}$ & $\begin{array}{c}\text { Phloem, } \boldsymbol{\mu m} \\
\text { Floem, } \mu \mathrm{m}\end{array}$ & $\begin{array}{c}\text { Ratio P/X } \\
\text { Omjer F/K }\end{array}$ \\
\hline $\begin{array}{l}\text { Heating } \\
\text { Grijanje }\end{array}$ & 1109.10 & 247.75 & 0.24 \\
\hline $\begin{array}{l}\text { Cooling } \\
\text { Hlađenje }\end{array}$ & 1789.15 & 333.02 & 0.22 \\
\hline $\begin{array}{l}\text { Control } \\
\text { Kontrola }\end{array}$ & 1569.54 & 289.42 & 0.21 \\
\hline
\end{tabular}

ring widths is a common characteristic of tree species and was not a result of our experiment (Fig. 4). The trees with wider growth rings in 2007 also had wider xylem increments in 2006 and vice versa (heated trees $=1028.5 \mu \mathrm{m}$, cooled trees $=1665.25 \mu \mathrm{m}$ and control trees $=1494.5 \mu \mathrm{m})$. The variability in the increment widths was less expressed on the phloem side (Table 1 ), as already reported in previous studies on sessile oak (Gričar, 2010). Xylem and phloem increments were widest in the cooled samples (on average 1789.15 and $333.05 \mu \mathrm{m}$, respectively) and narrowest in the heated samples (1190.10 and $274.74 \mu \mathrm{m})$. The anatomical structure of the xylem growth rings in 2007 remained unchanged in the temperature treated stem portions.

\subsection{Experiments on young A. pseudoplatanus trees in 2008}

3.3. Eksperimenti na mladim stablima $A$.

pseudoplatanus u 2008.

At the beginning of the experiment, on 29 February 2008, the dormant cambium was 5-7 cell layers wide in all sycamore maples. Three weeks later (midMarch), the cambium of the control and heated trees was still not active; however, expansion of the initial sieve tubes of early phloem from the overwintered cambial cells had already started (without previous cell
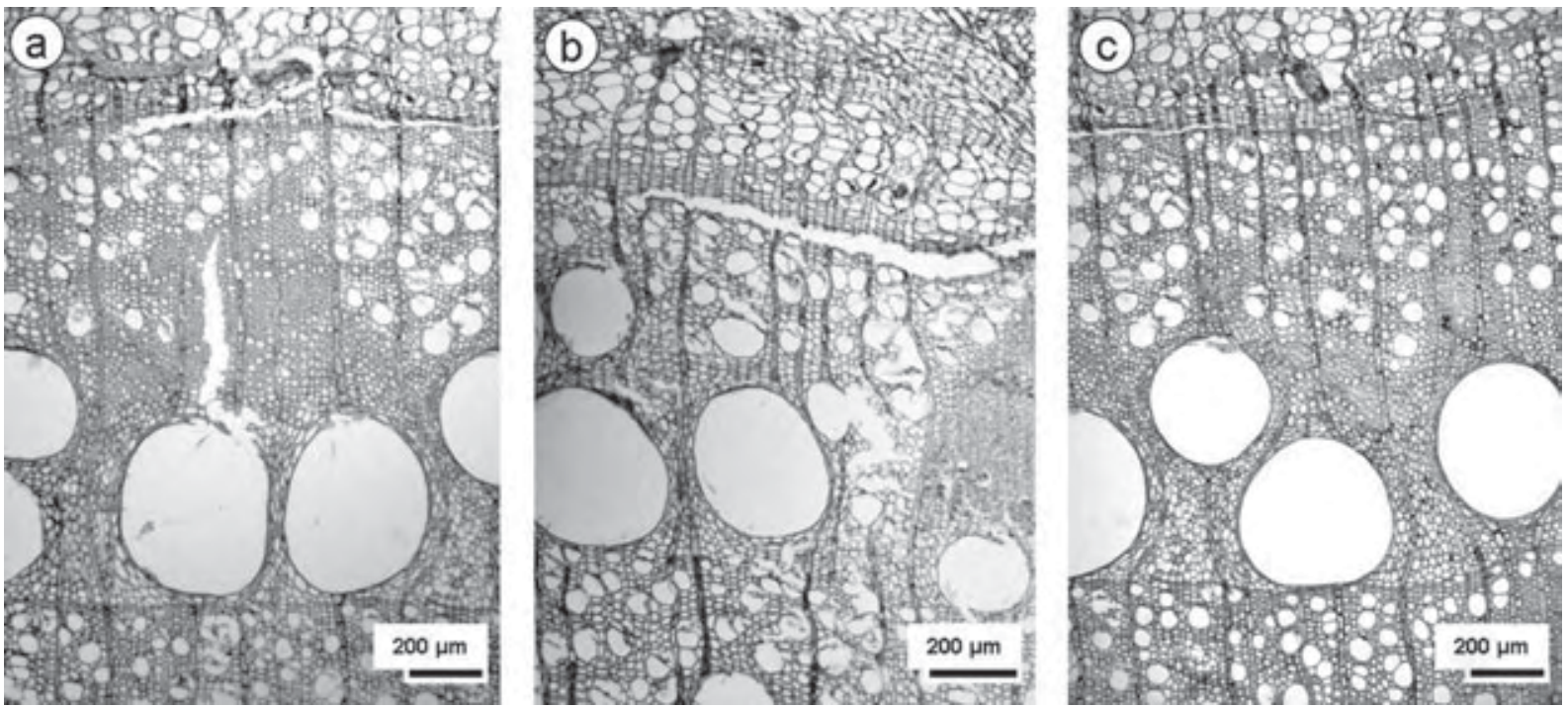

Figure 4 Xylem and phloem growth rings in the heated (a), cooled (b) and control (c) trees in 2007

Slika 4. Godovi ksilema i floema u grijanome (a), hlađenome (b) i kontrolnom (c) stablu u 2007. 

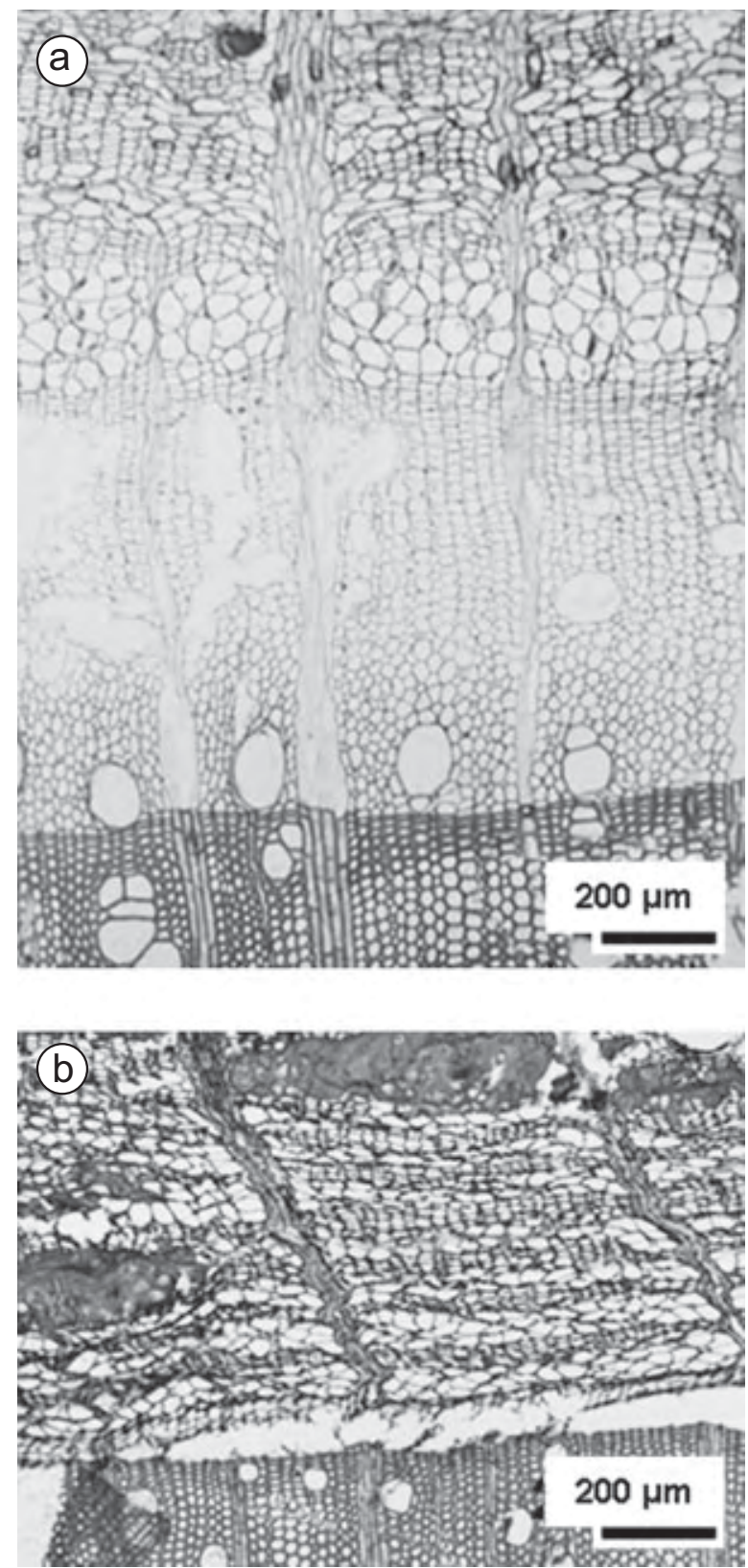

Figure 5 Developing xylem and phloem growth rings of 2008 in control sycamore maples in mid-June (a); dead cambial and living bark tissues in the heated trees (b) Slika 5. Nastajući godovi ksilema i floema u 2008. u kontrolnom stablu gorskog javora sredinom lipnja (a); mrtvo staničje kambija i žive kore u grijanim stablima (b)

division) in the latter trees. On 10 April, the cambium and living phloem of the heated trees showed the first signs of decaying, as indicated by disintegrated and collapsed living content of cambial cells and phloem ray and axial parenchyma cells. During a 3-week period (i.e., from 19 March to 10 April) the cambium reactivated, since the number of cambial cells increased up to 7-9 layers, but it died before producing new xylem or phloem cells. Cambium of the controls was still inactive at that time. At the end of April, cambial cell division also started in the control samples and we could subsequently follow the development of xylem and phloem growth rings of 2008 (Fig. 5a). In contrast, no new xylem or phloem cells were created in the heated stem portions (Fig. 5b). Inner, living bark of the in- sulated stem portion started to dry and turn brown, whereas it was still light-green and wet above the insulated stem portion, similarly as in the control trees (Fig. $6 \mathrm{~b}, \mathrm{~d})$. At the end of May, we detected a deterioration of the crown (i.e., leaves were drying and falling off) and the development of epicormic shoots at the base of the heated tree, above and below the insulated stem portion (Fig. 6a, c). In June, July and August, progressive decaying of the crown and formation of epicormic shoots occurred in the heated trees. Desiccation and dying of living tissues spread from the isolated stem portion towards the crown, which was clearly seen at the cellular level in the form of gradual destruction of cambial and phloem tissues in samples taken above the heated regions. The living bark and cambium dried up, so the bark separated from the wood (Fig. 5b). Repeatedly taken samples over the growing season of 2008 showed that the cambium of the heated stem portion did not produce any xylem or phloem cells. Its vitality started to decline rapidly after the applied heat treatment. At the end of our experiment, in mid-September, the crowns of the heated trees were dead and epicormic shoots also started to die. In the spring 2009, these trees were dead and the bark began to fall off, indicating beyond doubt that our treatment terminally damaged the young sycamore maples.

We began the cooling experiments in mid-April and continued until the end of the 2008 growing season. Samples taken at the beginning of May indicated that applied low temperatures slowed down the reacti-
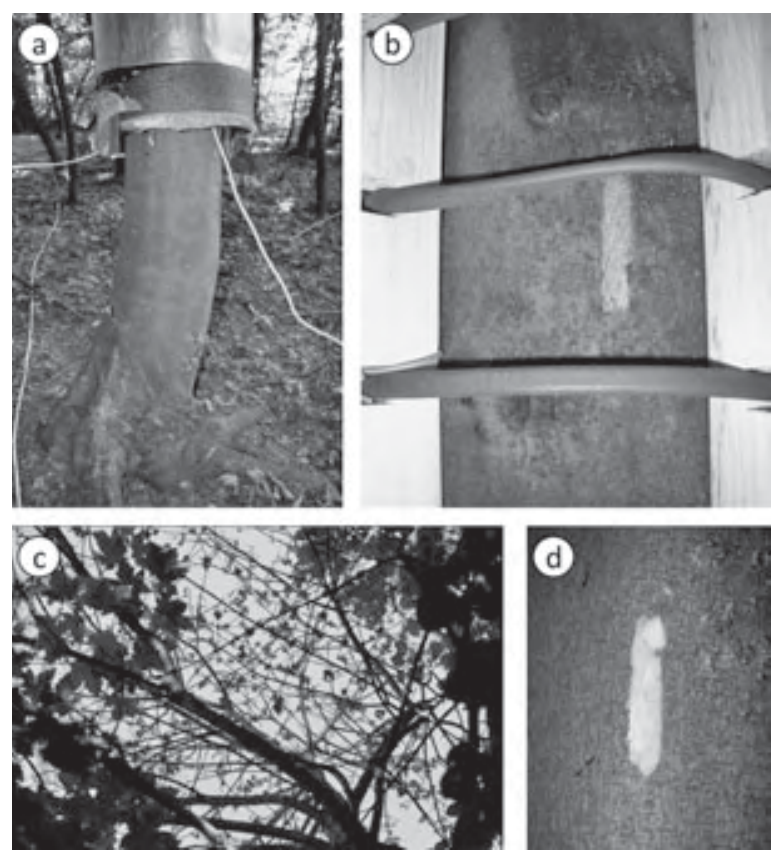

Figure 6 Formation of the first epicormic shoots at the base of the heated sycamore maples at the end of May (a); dark coloured dead living bark two months after the beginning of the heating (b); damaged crown of heated sycamore maples (c); light coloured living bark of the control trees (d) Slika 6. Stvaranje prvih adventivnih izdanaka u žilištu grijanih stabala gorskog javora potkraj svibnja (a); smeđe obojena umrla živa kora dva mjeseca nakon početka grijanja (b); oštećena krošnja grijanih stabala gorskog javora (c); svjetlozelena živa kora kontrolnih stabala (d) 

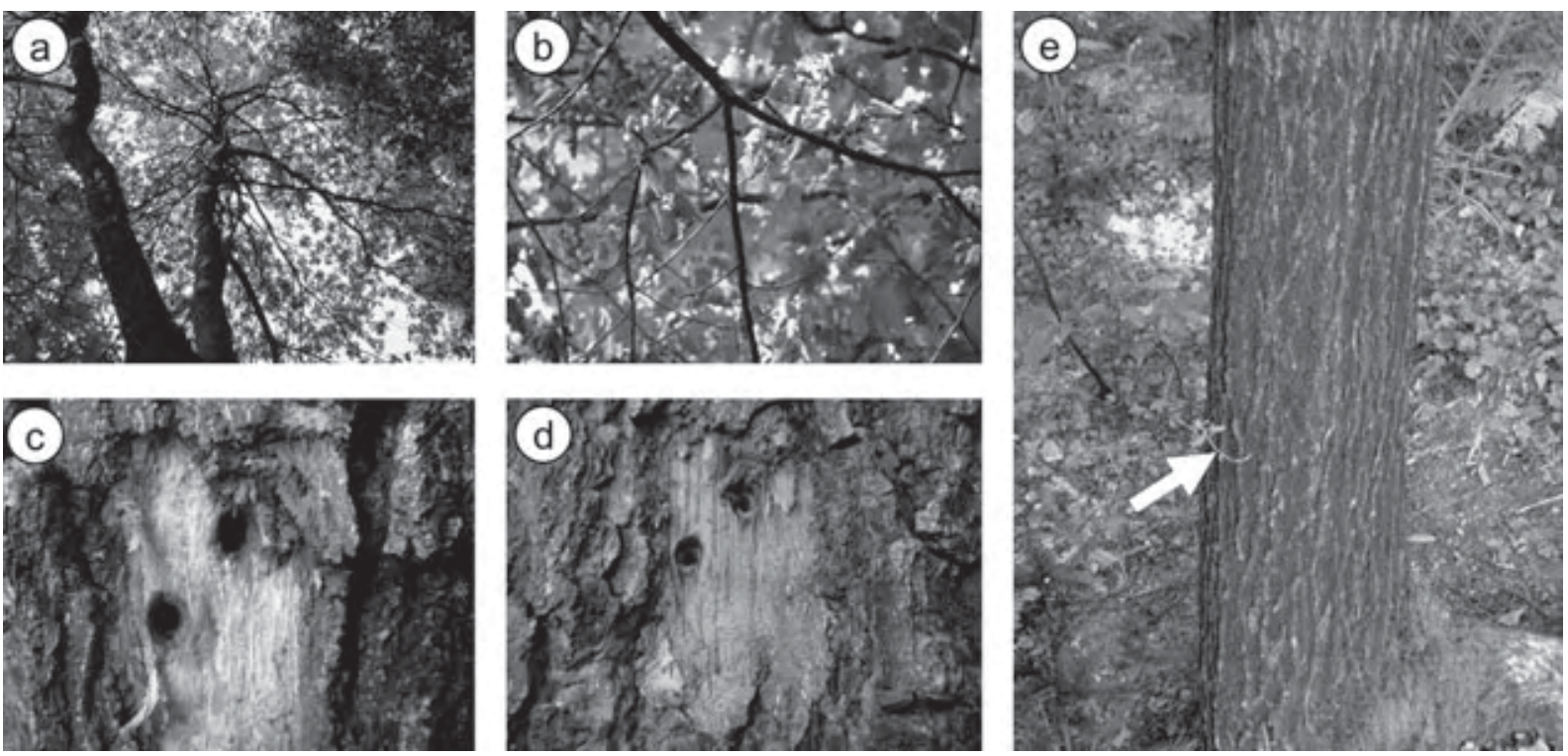

Figure 7 Damaged crown of heated sessile oak at the end of July (a, b); light coloured living bark of the control trees (c) and dark coloured dead living bark of the heated tree (d); formation of the first epicormic shoot (arrow) at the base of the tree (e) Slika 7. Oštećena krošnja grijanih stabala hrasta kitnjaka potkraj srpnja (a, b); svijetlo obojena živa kora kontrolnih stabala (c) i smeđa umrla živa kora grijanog stabla (d); stvaranje prvih adventivnih izdanaka u žilištu stabla

vation of cambium compared with the controls but no effect of cool treatments was detected in the following months in these samples in terms of a changed dynamics of phloem or xylem development. Differences were noticed in the widths of xylem and phloem increments among the trees and samples taken, and they were attributed to normal variability within and among trees and were not a result of the applied treatment. Cessation of cambial activity occurred at the end of August in the cooled and control samples.

\subsection{Experiments on young Q. sessiliflora in 2009 \\ 3.4. Eksperimenti na mladim stablima Q. sessiliflora u 2009.}

In view of the different reactions of old sessile oaks and young sycamore maples to the applied treatments, we started to assume that the age of a tree might be one of the reasons for a different response of the cambium to elevated or decreased temperatures. More specifically, the increasing thickness of dead bark with the aging of trees may have contributed to their different response. The onset of dead bark formation (i.e., additional layers of peridermis) is species specific and had not yet started to form in the sycamore maples involved in our study. It is commonly known that the dead part of the bark functions as a very good isolation layer for the sensitive inner, living bark and cambial tissues, thus protecting them from external abiotic and biotic factors (e.g., Nicolai, 1989). In order to confirm our assumptions, we selected young sessile oak trees of similar age as sycamore maples and exposed them to elevated temperatures during the growing season of 2009.

In contrast to the young sycamore maples, the sessile oaks of the same age already had dead bark, but it was relatively thin (up to $0.5 \mathrm{~cm}$ ). The first signs of decay of the young sessile oaks were visible around 4 months after the applied heat treatment. Apart from a time lag, the process of degradation was similar as in sycamore maples; i.e., the formation of epicormic shoots at the base of the trees, desiccation of the bark in the heated stem portions with its slow spread along the stem and deterioration of the crown (Fig. 7). It is plausible that this relatively thin layer of dead bark was able to provide temporary protection of the living phloem and meristem tissues from steadily elevated temperatures, but only for a short period of time.

\subsection{Effect of applied heat treatments on trees of different age}

3.5. Utjecaj promjena temperature na stabla različite dobi

The heating experiments that we performed on different tree species revealed that the impact of bark thickness (linked with tree age) on cambium response cannot be neglected (Table 2). Summarizing the results of such experiments, it was shown that the heating effect was most distinctive in young trees (30-year old sessile oak and sycamore maple) without or with a very thin layer of dead bark. In this case, the short-term effect of heating was positive, since it stimulated cambial cell division; however, in the long-term its influence was negative because it caused the death of the trees. In a 70 -year old Norway spruce with about $0.5 \mathrm{~cm}$ thick dead bark, the cambium response to heat treatment was positive, especially in the first part of the growing season, since elevated temperatures promoted cell division, resulting in wider phloem and xylem increments. Finally, 150-year old sessile oaks with more than $1 \mathrm{~cm}$ thick bark showed no response in the phloem or xylem anatomy/width to continuously elevated temperatures.

\section{DISCUSSION \\ 4. DISKUSIJA}

Our results suggest that the response of cambium to elevated/decreased temperatures in stem portions of 
Table 2 Comparison of the heating effect on cambial activity and cell differentiation in stem portions of different tree species of different age and dead bark thickness

Tablica 2. Usporedba učinka grijanja na aktivnost kambija i diferencijaciju stanica u dijelovima debala drveća različite vrste i starosti te s različito debelom mrtvom korom

\begin{tabular}{|l|c|c|c|l|}
\hline \multicolumn{1}{|c|}{$\begin{array}{c}\text { Tree species } \\
\text { Vrsta drveta }\end{array}$} & $\begin{array}{c}\text { Age of the tree, years } \\
\text { Starost drveća, godine }\end{array}$ & $\begin{array}{c}\text { DBH, cm } \\
\text { Promjer na prsnoj } \\
\text { visini, cm }\end{array}$ & $\begin{array}{c}\text { Thickness of dead bark, cm } \\
\text { Debljina mrtve kore, cm }\end{array}$ & $\begin{array}{c}\text { Effect of heating } \\
\text { Učinak grijanja }\end{array}$ \\
\hline $\begin{array}{l}\text { Sessile oak } \\
\text { hrast kitnjak }\end{array}$ & 150 & 70 & 0.5 & $\begin{array}{l}\text { No } \\
\text { nema ga }\end{array}$ \\
\hline $\begin{array}{l}\text { Norway spruce } \\
\text { obična smreka }\end{array}$ & 70 & 35 & $\begin{array}{l}\text { In xylem and phloem } \\
\text { u drvu i liku }\end{array}$ \\
\hline $\begin{array}{l}\text { Sessile oak } \\
\text { hrast kitnjak }\end{array}$ & 30 & 15 & 0.5 & $\begin{array}{l}\text { Death after 4 months } \\
\text { smrt nakon 4 mjeseca }\end{array}$ \\
\hline $\begin{array}{l}\text { Sycamore maple } \\
\text { gorski javor }\end{array}$ & 30 & 15 & $\begin{array}{l}\text { Death after 2 months } \\
\text { smrt nakon 2 mjeseca }\end{array}$ \\
\hline
\end{tabular}

different tree species depends not only on the age of the tree (in terms of dead bark thickness) but also on the duration of the applied treatments. The short-term effect (1-2 months) of heating juvenile trees with thin or no dead bark stimulated cell division in the cambium and cell differentiation, while long-term treatments led to the death of the tree. On the other hand, old trees with thick dead bark responded to the heat treatments only at the beginning of the growing season, as seen by a slightly faster cell wall formation and lignification of the initial xylem cells in old sessile oaks; no (devastating) effects were detected in the long-term. Cessation of cambial activity was not prolonged and also the structure and widths of xylem and phloem increments remained unchanged.

Our observations are in contrast with previous findings of similar experiments with elevated temperature carried out by other scientists on different tree species (Abies sachalinensis, Larix leptolepis, Cryptomeria japonica, Populus sieboldii x P. grandidentata) (e.g., Oribe and Kubo, 1997; Oribe et al, 2001, 2003; Begum et al, 2007, 2010). However, in their cases the selected trees were either relatively young (12-40 years old) or they were exposed to elevated temperatures only for a short period of time (i.e., one month). In addition, experiments were mainly performed during the dormant period. In the listed tree species, the application of heat stimulated cell division in the cambium and cell differentiation. Cambial cells of evergreen conifers (Abies sachalinensis, Cryptomeria japonica, Picea abies and Picea sitchensis) at the quiescent stage of cambial dormancy, which is imposed by external factors, can re-initiate cell division independently of the growth of new shoots and the development of buds in spring (Oribe and Kubo, 1997; Oribe et al, 2001, 2003; Gričar et al, 2006). On the other hand, heating did not stimulate cell division in cambium before regular cambial activity in the deciduous Larix leptolepis, which appeared only after the activation of buds (Oribe et al, 2001). Cambial reactivation in Populus sieboldii x $P$. grandidentata occurred before bud burst, indicating their independence of each other (Begum et al, 2007). Begum et al (2010) reported that cambial sensitivity from late winter to early spring under natural conditions and in locally heated stems of Cryptomeria japonica might depend both on cambial age and the stage of cambial dormancy. Cambial reactivation was induced earlier and xylem differentiation started sooner in 55-year old cambium at breast height than 80-year old cambium at the same height under natural conditions (Begum et al, 2010).

The first long-term experiments with elevated and decreased temperature were carried out on Norway spruces, aged around 70 years and with a dead bark thickness of about $0.5 \mathrm{~cm}$ (Gričar et al, 2007). The response of the cambium to heat treatment was positive, especially in the first part of the growing season, since elevated temperatures promoted cell division and differentiation, resulting in wider phloem and xylem increments. Cooling treatments, on the other hand, slowed down and shortened cell production and differentiation periods, so xylem and phloem rings were reduced by about one third. The experiment indicated that temperatures have greater impact on cambial cell production at the very beginning of the growing season, whereas other factors prevail in the period of late wood formation (Gričar et al, 2007).

Based on the latest results, we presume that the dead part of the bark might function as a very good isolation layer for sensitive inner, living bark and cambial tissues, thus protecting them from external abiotic and biotic factors. Bark thickness varies greatly not only with age, but also in different species; with oaks, periderms are formed quickly, one after another, forming dead bark together with dead, older and collapsed secondary phloem. We suspect that experimentally elevated temperatures did not influence cambial activity in old sessile oaks merely due to the fact that they had very thick bark, which prevented the temperatures from reaching the cambium. That would also explain the absence of changes in the dynamics of cambial activity and cell differentiation. With young sessile oaks and sycamore maples, the effect was the reverse, since the experimental trees were young with very thin or no dead bark, so the heating of the living part of the bark and cambium tissues was very intense. It seems that long-term heating was fatal for these trees, since they started to die a few months after exposure to elevated temperatures.

Deterioration of the crown resulted in the formation of epicormic shoots at the base of the sycamore 
maples and sessile oaks. Epicormic shoots arise from latent buds on the stem of a tree that are stimulated in the case of stress, such as sudden environmental change, crown dieback, thinning, heavy pruning, root death, cold and change in the water table (e.g., Fontaine et al, 1998). In addition to genetic determinism in some tree species, their appearance is also linked to abrupt changes in a tree environment (Nicolini et al, 2001). Supressed or moribund trees with low cambial activity often produce numerous epicormic branches on the base of the stem in order to form a new crown to replace the old, ineffective and dying one. However, secondary growth does not resume until epicormic branch formation slows down or stops, several years after the first epicormic branches are formed, suggesting that other conditions have to be fulfilled before cambial growth can resume. Assimilates produced by the first epicormic branches may initially be used to ensure their perenniality and enable the formation of new branches, but probably also to resume growth of the root system, which may also show reduced development (Nicolini et al, 2001).

When cambium necrosis occurs around the entire stem circumference (girdling), the stem will be unable to regenerate phloem and xylem in that area. When a tree is girdled by fire, cambium necrosis is always accompanied by phloem necrosis because phloem is external to the cambium. The crown of a girdled tree will continue to fix carbon and grow, but with a phloem girdle photosynthates will not be transported to the roots. The root system must rely on carbohydrate reserves; these reserves will eventually be depleted, fine-root production will cease and the tree will die from water stress. Reductions in leaf area and fine-root area will also affect tree carbon and water budgets (Michaletz and Johnson, 2007).

Research results support the theory of older trees with a thicker bark being more resistant to fires (e.g., Michaletz and Johnson, 2007). Tree bark structure also has an important ecological function; trees growing in open canopy in arid ecosystems often have richly structured, thick bark because of a higher risk of sun burn due to solar radiation reaching the trunks (Nicolai, 1989).

The timing of cambial reactivation plays an important role in determination of the amount and quality of wood and environmental adaptivity of trees. The response of cambium and wood formation processes to experimental heating or cooling depends on the tree species (e.g., Oribe et al, 2003; Begum et al, 2007). Temperature treatments have shown a different effect on cambial activity and cell differentiation in evergreen and deciduous conifers and angiosperms, although tree age in combination with bark thickness appears to influence the extent of this effect. In addition, the duration of the applied treatments also has an impact on long-term cambial response. Our findings show that factors affecting cambial activity are numerous and interact in a complex way, which needs to be taken into consideration in order to understand cambial response to applied heat/cool treatments. However, further in- vestigations on the same species with trees of different age need to be carried out in order to confirm our speculations. Finally, our findings are also important in the context of a potential response of trees to a changing climate; especially to the rise in summer temperatures.

\section{Acknowledgements - Zahvale}

Thanks to Špela Jagodic and Robert Krajnc from the Slovenian Forestry Institute for their invaluable help in the field and laboratory. Thanks to the three reviewers, who provided numerous useful comments that have been incorporated into the manuscript. The work was supported by the Slovenian Research Agency through projects Z4-9662, V4-0496, L7-2393 and P40107.

\section{REFERENCES}

\section{LITERATURA}

1. Barnett, J. R.; Miller, H., 1994: The effect of applied heat on graft union formation in dormant Picea sitchensis (Bong.) Carr. J. Exp. Bot. 45 (1): 135-143.

http://dx.doi.org/10.1093/jxb/45.1.135

2. Begum, S.; Nakaba, S.; Oribe, Y.; Kubo, T.; Funada, R., 2007: Induction of cambial reactivation by localized heating in a deciduous hardwood hybrid poplar (Populus sieboldii $\mathrm{x}$ P. grandidentata). Ann. Bot. 100 (3): 439-447. http://dx.doi.org/10.1093/aob/mcm130

3. Begum, S.; Nakaba, S.; Bayramzadeh, V.; Yuichiro, O.; Kubo, T.; Funada, R., 2008: Temperature responses of cambial reactivation and xylem differentiation in hybrid poplar (Populus sieboldii $\times$ P. grandidentata) under natural conditions. Tree Physiol. 28 (12): 1813-1819.

http://dx.doi.org/10.1093/treephys/28.12.1813

4. Begum, S.; Nakaba, S.; Yuichiro, O.; Kubo, T.; Funada, R., 2010: Cambial sensitivity to rising temperatures by natural condition and artificial heating from late winter to early spring in the evergreen conifer Cryptomeria japonica. Trees-Struct. Funct. 24 (1): $43-52$.

http://dx.doi.org/10.1007/s00468-009-0377-1

5. Begum, S.; Nakaba, S.; Islam, Md. A.; Yamagishi, Y.; Funada, R., 2012: Effects of low temperature in reactivated cambial cells induced by localized heating during winter dormancy in conifers. Am. J. Plant Physiol. 7 (1): 30-40. http://dx.doi.org/10.3923/ajpp.2012.30.40

6. Chaffey, N., 2002: Introduction. U: N. Chaffey (Ed.): Wood formation in trees: Cell and molecular biology techniques. London New York, Taylor \& Francis, pp. 1-8.

7. De Luis, M.; Novak, K.; Raventós, J.; Gričar, J.; Prislan, P.; Čufar, K., 2011: Cambial activity, wood formation and sapling survival of Pinus halepensis exposed to different irrigation regimes. For. Ecol. Manage. 262 (8): 1630-1638.

http://dx.doi.org/10.1016/j.foreco.2011.07.01

8. Denne, M. P.; Dodd, R. S., 1981: The environmental control of xylem differentiation. U: J.R. Barnett (Ed.): Xylem Cell development. Tunbridge Wells, UK, Castle House Publications Ltd, pp. 236-255.

9. Fontaine, F.; Druelle, J.-L.; Clément, C.; Burrus, M.; Audran, J.-C., 1998: Ontogeny of proventitious epicormic buds in Quercus petraea. I. In the 5 years following initiation. Trees-Struct. Funct. 13 (1): 54-62. http://dx.doi.org/10.1007/PL00009737

10. Gričar, J.; Zupančič, M.; Čufar, K.; Koch, G.; Schmitt, U.; Oven, P., 2006: Effect of local heating and cooling on 
cambial activity and cell differentiation in stem of Norway spruce. Ann. Bot. 97 (6): 943-951. http://dx.doi.org/10.1093/aob/mcl050

11. Gričar, J.; Zupančič, M.; Čufar, K.; Oven, P., 2007: Regular cambial activity and xylem and phloem formation in locally heated and cooled stem portions of Norway spruce. Wood Sci. Technol. 41 (6): 463-475. http://dx.doi.org/10.1007/s00226-006-0109-2

12. Gričar, J., 2010: Xylem and phloem formation in sessile oak from Slovenia in 2007. Wood Research 55 (4): 15-22.

13. Grünwald, C.; Ruel, K.; Schmitt, U., 2002: Differentiation of xylem cells in rolC transgenic aspen trees - a study of secondary wall development. Ann. For. Sci. 59 (5/6): $679-685$. http://dx.doi.org/10.1051/forest:2002056

14. Larcher, W., 2003: Physiological plant ecology. Ecophysiology and stress physiology of functional groups. Fourth edition. Berlin, Heidelberg, Springer - Verlag. http://dx.doi.org/10.1007/978-3-662-05214-3

15. Meier, I. C.; Leuschner, C., 2008: Leaf size and leaf area index in Fagus sylvatica forests: Competing effects of precipitation, temperature, and nitrogen availability. Ecosystems 11 (5): 655-669. http://dx.doi.org/10.1007/s10021-008-9135-2

16. Mellerowicz, E. J.; Coleman, W. K.; Riding, R. T.; Little, C. H. A., 1992: Periodicity of cambial activity in Abies balsamea. I. Effects of temperature and photoperiod on cambial dormancy and frost hardiness. Physiol. Plantarum 85 (3): 515-525.

http://dx.doi.org/10.1111/j.1399-3054.1992.tb05820.x

17. Mellerowicz, E. J.; Baucher, M.; Sundberg, B.; Boerjan, W., 2001: Unravelling cell wall formation in the woody dicot stem. Plant Mol. Biol. 47 (1/2): 239-274. http://dx.doi.org/10.1023/A:1010699919325

18. Michaletz, S. T.; Johnson, E. A., 2007: How forest fires kill trees: A review of the fundamental biophysical processes. Scand. J. Forest Res. 22 (6): 500-515. http://dx.doi.org/10.1080/02827580701803544

19. Nicolai, V., 1989: Thermal properties and fauna on the bark of trees in two different African ecosystems. Oecologia 80 (3): 421-430. http://dx.doi.org/10.1007/BF00379046

20. Nicolini, E.; Chanson, B.; Bonne, F., 2001: Stem growth and epicormic branch formation in understorey beech trees (Fagus sylvatica L.) Ann. Bot. 87 (6): 737-750. http://dx.doi.org/10.1006/anbo.2001.1398

21. Oribe, Y.; Kubo, T., 1997: Effect of heat on cambial reactivation during winter dormancy in evergreen and deciduous conifers. Tree Physiol. 17 (2): 81-87. http://dx.doi.org/10.1093/treephys/17.2.81
22. Oribe, Y.; Funada, R.; Shibagaki, M.; Kubo, T., 2001: Cambial reactivation in locally heated stems of the evergreen conifer Abies sachalinensis (Schmidt) Masters. Planta 212 (5/6): 684-691.

http://dx.doi.org/10.1007/s004250000430

23. Oribe, Y.; Funada, R.; Kubo, T., 2003: Relationships between cambial activity, cell differentiation and the localization of starch in storage tissues around the cambium in locally heated stems of Abies sachalinensis (Schmidt) Masters. Trees-Struct. Funct. 17 (3): 185-192. http://dx.doi.org/10.1007/s00468-002-0231-1

24. Plomion, C.; Leprovost, G.; Stokes, A., 2001: Wood formation in trees. Plant Physiol. 127 (4): 1513-1523. http://dx.doi.org/10.1104/pp.010816

25. Rossi, S.; Anfodillo, T.; Menardi, R., 2006: Trephor: a new tool for sampling microcores from tree stems. IAWA J. 27 (1): 89-97. http://dx.doi.org/10.1163/22941932-90000139

26. Rossi, S.; Simard, S.; Rathgeber, C. B. K.; Deslauriers A.; De Zan, C., 2009: Effects of a 20-day-long dry period on cambial and apical meristem growth in Abies balsamea seedlings. Trees-Struct. Funct. 23 (1): 85-93. http://dx.doi.org/10.1007/s00468-008-0257-0

27. Savidge, R.A., 2001: Intristic regulation of cambial growth. J. Plant Growth Regul. 20 (1): 52-77. http://dx.doi.org/10.1007/s003440010002

28. Sundberg, B.; Uggla, C.; Tuominen, H., 2000: Cambial growth and auxin gradients. U: R. A. Savidge; J. R. Barnett; R. Napier (Eds.): Cell and Molecular Biology of Wood Formation. Oxford, UK, BIOS Scientific Publishers Limited, pp. 169-188.

29. Wodzicki, T.J., 2001: Natural factors affecting wood structure. Wood Sci. Technol. 35 (1/2): 5 -26. http://dx.doi.org/10.1007/s002260100085

\section{Corresponding address:}

Assistant Professor JOŽICA GRIČAR, Ph.D.

Slovenian Forestry Institute

Department of Yield and Silviculture

Večna pot 2

SI-1000 Ljubljana, SLOVENIA

e-mail: jozica.gricar@gozdis.si 